\title{
Stationary Fuel Cell Application Codes and Standards: Overview and Gap Analysis
}

Technical Report NREL/TP-560-49165

September 2010

Chad W. Blake and Carl H. Rivkin 


\section{Stationary Fuel Cell Application Codes and Standards: Overview and Gap Analysis}

Chad W. Blake and Carl H. Rivkin

Prepared under Task No. H274.7170

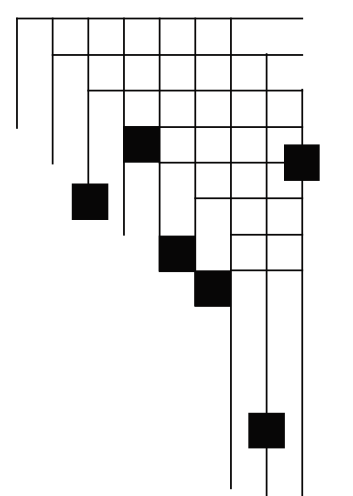




\section{NOTICE}

This report was prepared as an account of work sponsored by an agency of the United States government. Neither the United States government nor any agency thereof, nor any of their employees, makes any warranty, express or implied, or assumes any legal liability or responsibility for the accuracy, completeness, or usefulness of any information, apparatus, product, or process disclosed, or represents that its use would not infringe privately owned rights. Reference herein to any specific commercial product, process, or service by trade name, trademark, manufacturer, or otherwise does not necessarily constitute or imply its endorsement, recommendation, or favoring by the United States government or any agency thereof. The views and opinions of authors expressed herein do not necessarily state or reflect those of the United States government or any agency thereof.

Available electronically at http://www.osti.gov/bridge

Available for a processing fee to U.S. Department of Energy and its contractors, in paper, from:

U.S. Department of Energy

Office of Scientific and Technical Information

P.O. Box 62

Oak Ridge, TN 37831-0062

phone: 865.576 .8401

fax: 865.576 .5728

email: mailto:reports@adonis.osti.gov

Available for sale to the public, in paper, from:

U.S. Department of Commerce

National Technical Information Service

5285 Port Royal Road

Springfield, VA 22161

phone: 800.553.6847

fax: 703.605.6900

email: orders@ntis.fedworld.gov

online ordering: http://www.ntis.gov/ordering.htm 


\section{Executive Summary}

Codes and standards are implemented to ensure that processes and products meet uniform requirements. These requirements pertain to either safety or performance specifications. The Codes and Standards Group at the National Renewable Energy Laboratory (NREL) conducted an analysis of the full range of codes and standards that apply to stationary fuel cell applications to determine where the gaps are located in the codes and standards and what work must be performed to fill these gaps. The major codes and standards are in place to allow for the implementation of stationary fuel cells. Fuel cells projects may be slowed by issues of coordination or clarity in codes and standards but are not being stopped by these gaps. The fuel cell technologies that are making the most commercial progress are:

1. Polymer Electrolyte Membrane (PEM) fuel cells used primarily for backup power

2. Phosphoric Acid fuel cells

3. Solid Oxide Fuel Cells

4. Molten Carbonate fuel cells.

Table 1 summarizes key gaps in existing stationary fuel cell application codes and standards identified during analysis. The individual sections provide additional extensive listings of codes and standards gaps. The gaps listed in this table were deemed more important by the authors or the experts interviewed by the authors.

This report was written with input from experts in stationary fuel cell applications. Table 2 identifies the various experts who provided input to this report.

Table 1: Summary of Stationary Fuel Cell Application Codes and Standards Gaps Stationary fuel cell application Codes and Standards Gap

\section{Documents} Impacted
Gap Resolution

\begin{tabular}{|l|l|l|}
\hline $\begin{array}{l}\text { Coordination between } \\
\text { installation documents } \\
\text { and design and } \\
\text { component standards }\end{array}$ & Multiple & $\begin{array}{l}\text { Ongoing monitoring } \\
\text { of the codes and } \\
\text { standards } \\
\text { development } \\
\text { process }\end{array}$ \\
\hline $\begin{array}{l}\text { Coordination between } \\
\text { domestic documents } \\
\text { and international } \\
\text { standards }\end{array}$ & Multiple & $\begin{array}{l}\text { Ongoing monitoring } \\
\text { of the codes and } \\
\text { standards } \\
\text { development } \\
\text { process }\end{array}$ \\
\hline
\end{tabular}




\begin{tabular}{|l|l|l|}
\hline $\begin{array}{c}\text { Stationary fuel cell } \\
\text { application Codes and } \\
\text { Standards Gap }\end{array}$ & $\begin{array}{c}\text { Documents } \\
\text { Impacted }\end{array}$ & Gap Resolution \\
\hline $\begin{array}{l}\text { Lack of understanding } \\
\text { of fuel cell technologies, } \\
\text { specifically the storage } \\
\text { of alternative fuels, on } \\
\text { the part of code officials }\end{array}$ & Multiple & $\begin{array}{l}\text { Outreach efforts to } \\
\text { code official and } \\
\text { project developers }\end{array}$ \\
\hline
\end{tabular}


Table 2: Codes and Standards Experts

\begin{tabular}{|l|l|l|}
\hline Expert & Organization & Area of Expertise \\
\hline Connie Bielawski & CSA America & Component Standards \\
\hline Chad Blake & NREL & Codes and Standards \\
\hline William Collins & UTC Power & Fuel Cells \\
\hline Michael Penev & NREL & Fuel Cell Analysis \\
\hline Chris Radley & Altergy Systems & Fuel Cell Systems \\
\hline Carl Rivkin & NREL & Codes and Standards \\
\hline Doug Wheeler & Consultant to NREL & Fuel Cells \\
\hline Joseph Zerbo & Salt River Project & Electric Utility \\
\hline
\end{tabular}




\section{$\underline{\text { Table of Contents }}$}

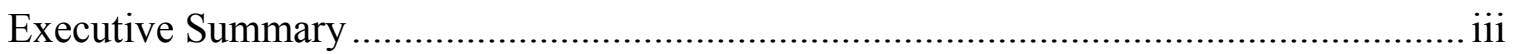

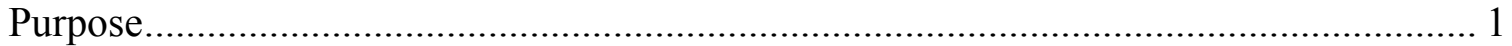

Codes and Standards - Generic Overview.................................................................. 2

Fuel Cell Technologies Codes and Standards Project ................................................... 4

Stationary Fuel Cell Technologies.......................................................................... 8

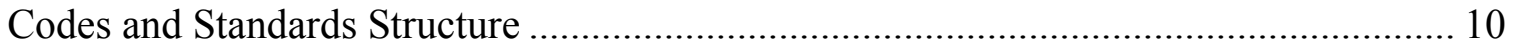

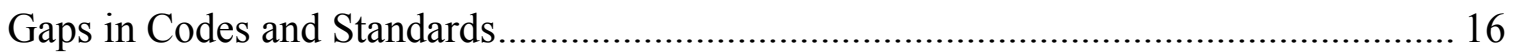

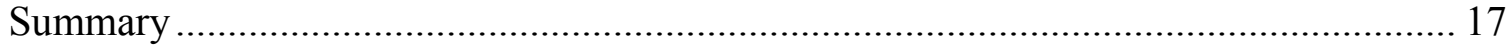

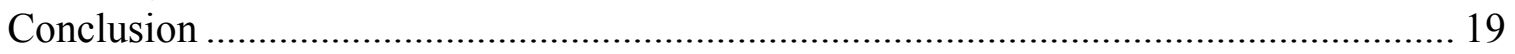

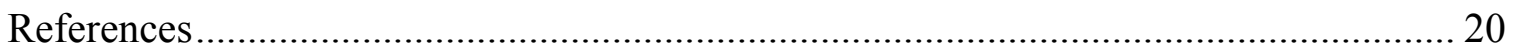

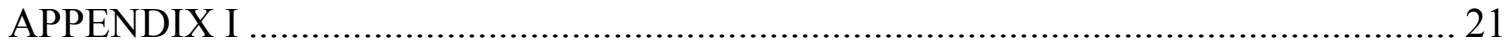

\section{List of Figures}

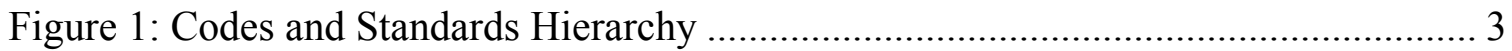

Figure 2: The NREL Codes and Standards Project ......................................................... 6

Figure 3: The Codes and Standards Development Process ................................................ 7

Figure 4: Stationary Fuel Cell Technologies [4]........................................................ 8

Figure 5: Comparison of Fuel Cell Technologies [7] ..................................................... 9

\section{List of Tables}

Table 1: Summary of Stationary Fuel Cell Application Codes and Standards Gaps.........iii

Table 2: Codes and Standards Experts............................................................................ v

Table 3: Code and Standard Citations for Stationary Fuel Cell Applications .................. 10

Table 4: Codes and Standards Gaps for Stationary Fuel Cell Applications ..................... 17 


\section{Purpose}

The purpose of this report is to identify gaps in stationary fuel cell application codes and standards and to recommend actions that provide a means to fill these gaps. The focus of this gap analysis is on stationary fuel cell applications. The existence of these gaps represents barriers to the implementation of stationary fuel cell systems. This analysis also identifies specific activity that leads to the elimination of the codes and standards gaps. These recommendations will help define codes and standards development work and priorities. This report presents a comprehensive summary of the codes and standard gaps for stationary fuel cell applications.

Codes and standards facilitate the development and implementation of new technologies. This is especially true in cases where commercial success is predicated upon contributions from multiple industries, such as stationary fuel cells. Stationary fuel cell equipment must be available that is compatible with other existing power equipment. At the same time, it is also required that fuel be available for the stationary fuel cell application, thereby requiring transit, storage, and transfer infrastructure. To ensure national security for the United States and to alleviate the dependence on imported fossil fuels, the U.S. Department of Energy (DOE) Fuel Cell Technologies Program supports the use of stationary fuel cells.

The use of alternative fuels is growing and the number of stationary fuel cell applications that operate on such fuel has dramatically increased in the past decade. Unique infrastructure impacts will be encountered, including production capacity and impact on existing demands and safety, as well as achieving appropriate stationary fuel cell application performance in a consumer market.

The number of stationary fuel cell applications powered by non-conventional alternative fuels is growing. To facilitate the development of the emerging markets, the stationary fuel cell application Codes and Standards Group at NREL initiated a study to identify specific gaps in the codes and standards structure for stationary fuel cell applications. This codes and standards analysis was broadened to include regulatory or policy issues that impede application of a technology. This gap analysis involved a comprehensive review of the existing codes and standards currently applied to each fuel type. To ensure a thorough analysis was performed, experts in the fuel cell industry with extensive handson experience were consulted. These experts provided unique insights into the status of the identified applications. The expert discussions were incorporated into the following analysis. See Appendix I for brief expert biographies. 


\section{Codes and Standards - Generic Overview}

Codes and standards are developed to ensure that processes and products meet uniform requirements. Codes and standards guide the implementation of energy technology by providing an accessible framework that sets unified engineering and design specifications. Performance specifications, component compatibility, and safety are all addressed by codes and standards. Although often interchangeable, the terms code and standard have distinct meanings and implications. Both should be written in legally enforceable language. However, as defined in fire and building codes, a code dictates that a requirement must be met and is often implemented and enforced by Authorities having Jurisdiction (AHJs). A standard defines how to fulfill the requirement dictated by the code. For example, a building code might require a certain type of building to use sprinkler protection. A sprinkler standard, which could be referenced within the code, specifies the requirements for building sprinkler systems. The standard, on its own, does not require anything; it merely defines metrics within the context of the standard itself. For enforceability, the standard is incorporated into a code or regulation that mandates compliance to the standard. Figure 1 illustrates the codes and standards hierarchy.

Codes, and by extension standards cited within codes, are legally enforceable documents when a jurisdiction adopts them either by reference or direct incorporation into the jurisdiction's regulations. Standards, referenced in the code, then become legally enforceable documents when the code is adopted. Codes and standards for the built environment are typically enforced at the local level by the town or county building and fire department, the typical AHJ for local governments. Stationary fuel cell application codes and standards are typically enforced at the federal (at government facilities) or state levels, which tend to have greater self-enforcement than built environment codes and standards.

Codes and standards in the United States are, for the most part, promulgated under a system of rules established by the American National Standards Institute (ANSI) [3]. Several Standards Development Organizations (SDOs) develop codes and standards according to ANSI rules for document development and maintenance. 


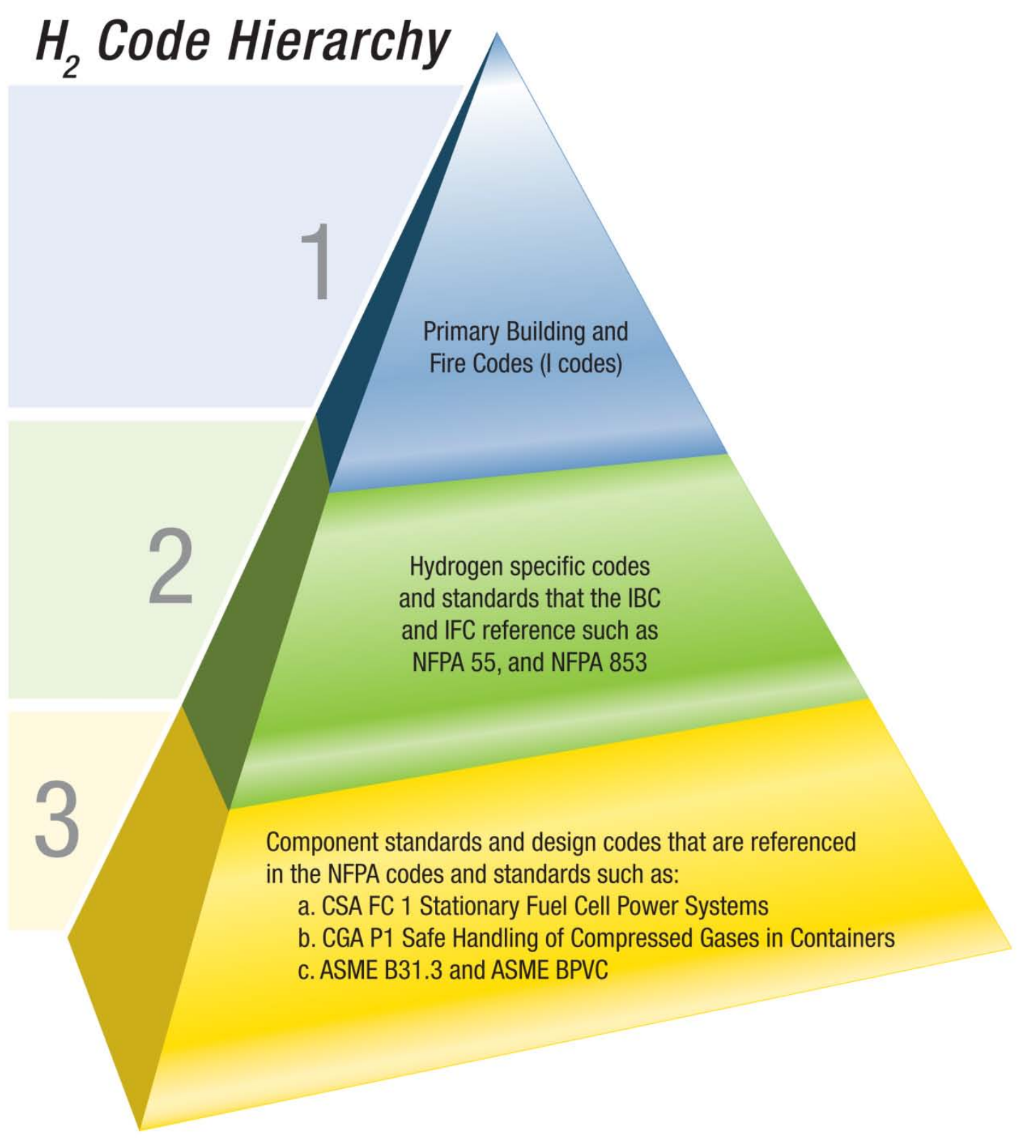

Figure 1: Codes and Standards Hierarchy 


\section{Fuel Cell Technologies Codes and Standards Project}

NREL's Codes and Standards Group applied a comprehensive approach to addressing codes and standards gaps for the Fuel Cell Technologies Program. Codes and standards issues as they related to safety, fuel quality, education and outreach programs, as well as production, transit, and storage infrastructure were addressed. The success of this activity clearly demonstrates that this approach would facilitate implementation of the other fuel cell applications. Accordingly, NREL's Codes and Standards Group addressed all stationary fuel cell application codes and standards. The approach used for hydrogen technologies, which included National Template for Codes and Standards, Research, Training and Outreach, and Codes and Standards Development, has been applied to all stationary fuel cell application codes and standards. Figure 2 illustrates the outline for the comprehensive Codes and Standards Program.

\section{National Templates}

A national template for specific stationary fuel cell applications has been developed. The template provides an overview of the codes and standards associated with stationary fuel cell applications. The codes and standards referenced in each section are intended to provide a comprehensive listing of codes and standards that pertain to stationary fuel cell applications.

\section{Research}

Often, sufficient data does not exist to allow for the defensible development of an enforceable standard. When the need for technical information for a code or standard is identified, a research program is initiated and designed to provide the necessary data. The research is performed within the national laboratory system, directly or through managed subcontracts, and the result is presented directly to the technical committee responsible for producing or revising a code or standard.

\section{Training and Outreach}

The NREL Codes and Standards Group has an active Training and Outreach Program, providing multi-media and on-site training opportunities for code officials and other stakeholders. Training opportunities for fuel cells are available through online resources, printed media, fact sheets, and on-site training workshops. Online resources include case studies of various facilities (e.g., cell towers and fueling stations), searchable databases of relevant codes organized by topic and code organization, and networking opportunities with personnel experienced in the permitting process. Special topics are also included online, such as the "Introduction to Hydrogen for Code Officials" short course [1]. Complementing the online resources are live training workshops and presentations to various code officials. Special emphasis is on the training workshop for permitting officials, of which more than 10 were held in two years [2]. The NREL Training and Outreach Program also provides Third Party Reviews for key programs (e.g., fork lift operations). Printed media includes handouts at workshops, and hydrogen fact sheets. The success of the Hydrogen Training and Outreach Program ensures that comparable programs for alternative fuels are highly beneficial. 


\section{Fuel Cell Technologies Codes and Standards Development Process}

Codes and standards development is occurring within the domestic market and in the international arena. Typically, codes and standards are written through a consensus process by a committee comprised of interested parties and stakeholders. To ensure a balanced representation among stakeholders during the development process, the committee is comprised of representatives from industry, end-users, and regulatory agencies. NREL is represented on several codes and standards technical committees as well as actively monitoring the activities of several committees. Using information from these technical committee activities, NREL determines where research or data are needed to help develop new codes and standards requirements, and also ensures harmonization between domestic and international standards. NREL conducts research at NREL or coordinates research so it is conducted at other DOE laboratories or independent laboratories under the auspices of DOE to produce the required information. NREL then presents this information directly to the codes and standards technical committees for use in document development. By working directly with the codes and standards development committees, NREL ensures that the information needed for new codes and standards requirements is presented directly to the committee and that committee members have an opportunity to discuss and, therefore, clearly understand the information. In addition, NREL's participation on the codes and standards committees ensures harmonization between standards. Figure 3 illustrates the NREL Codes and Standards development protocol, which is consistent with the procedure mandated by ANSI.

The process of working directly with the codes and standards technical committees has been effective. Several projects progressed as a result of this direct participation in the codes and standards development process, including the following:

1. National Fire Protection Association (NFPA) 2 Hydrogen Technologies Codes

2. ISO Draft International Standard (DIS) 26142 Hydrogen Detection Apparatus. 


\section{Codes and Standards Project}

National Template

Develop and manage

a National Template of

Codes and Standards.
Research Laboratory

Perform and coordinate research

to support the development of

codes and standards.

\section{Training and Outreach}

Create web training and information products for codes and standards. Perform on site training and regional workshops directed at project developers, code officials, and interested parties.
1. Develop and maintain a National Template of Codes and Standards.

2. Participate directly on codes and standards technical committees.

3. Identify gaps in the codes and standards and plan research to fill these gaps.

4. Harmonize domestic and international standards on an as needed basis.
1. Evaluate safety sensor performance according to established DOE performance criteria and distribute information to improve sensor performance.

2. Perform research identified under the codes and standards template gap analysis primarily within DOE laboratory facilities.

3. Work directly with the codes and standards technical committees to implement research products into the codes and standards.

4. Maintain and upgrade laboratory to meet the codes and standards research demands.
1. Produce web based training and information products to support the application of codes and standards.

2. Perform Codes and Standards training at NREL utilizing the Wind Site and other projects.

3. Perform regional codes and standards workshops.

4. From workshop feedback identify needed code changes and research projects.

5. Perform project codes and standards analyses and third party safety evaluations.

6. Support the Clean Cities Program.

Figure 2: The NREL Codes and Standards Project 


\section{Codes and Standards Development Process}

Directed by NREL Codes and Standards Project Manager

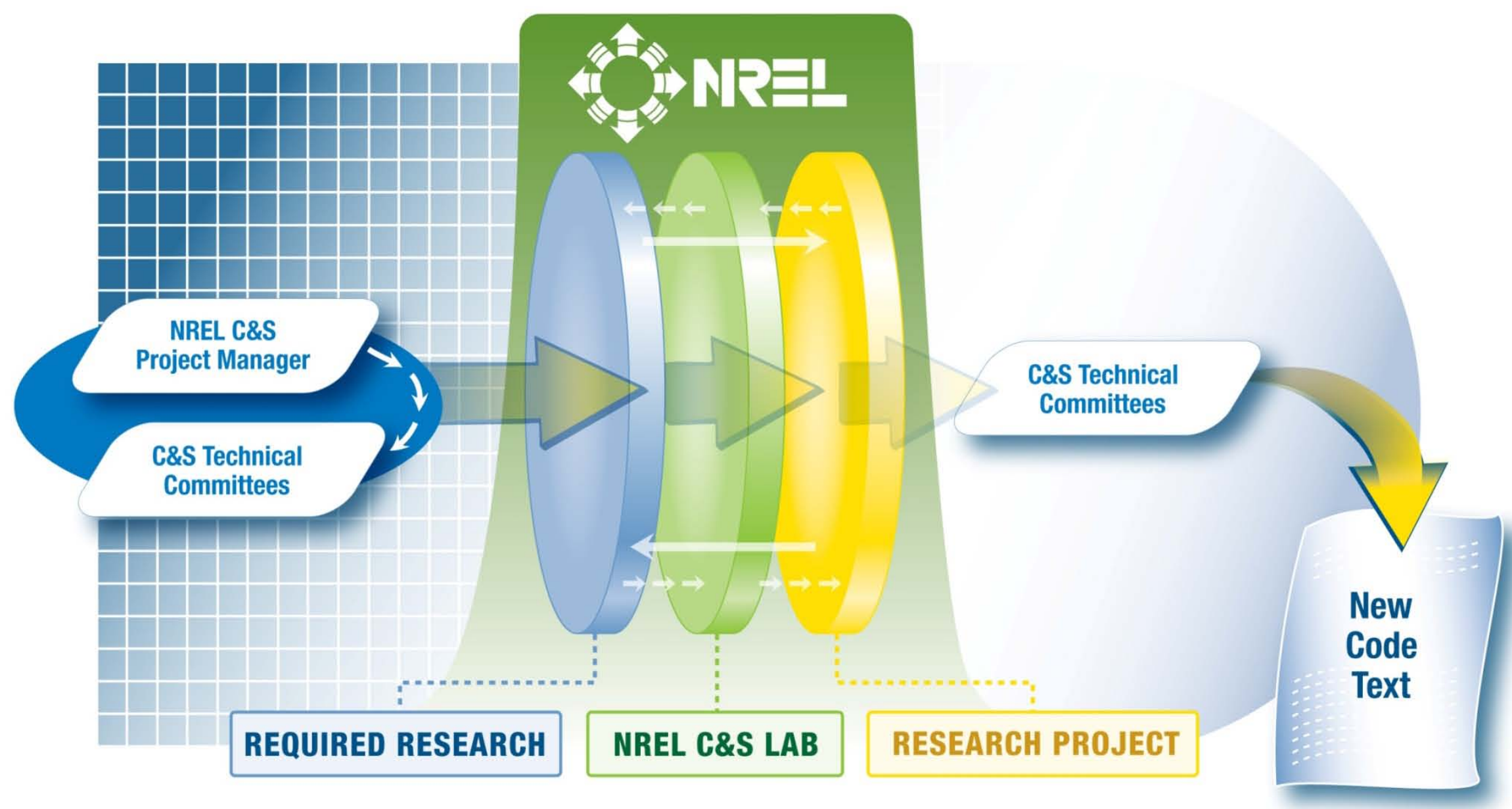

Figure 3: The codes and standards development process 


\section{Stationary Fuel Cell Technologies}

There are several types of stationary fuel cell technologies available today. The four most common types are shown in Figure 4. The primary difference between the technologies is the electrolyte and associated difference in optimum operating temperatures.

In all cases, the stationary fuel cell utilizes a fuel gas to produce electricity by the use of an electrolyte between an anode and cathode.

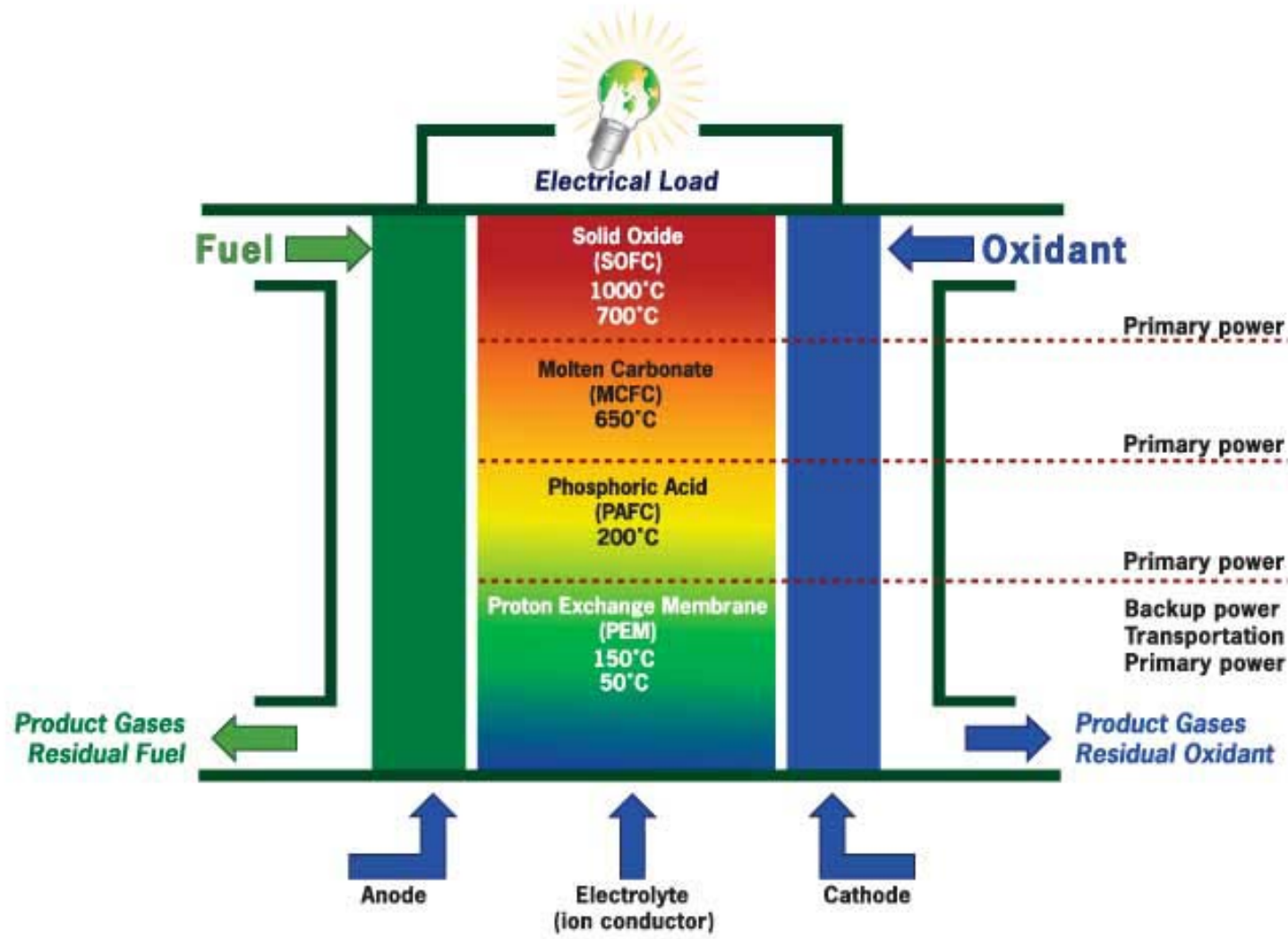

Figure 4: Stationary Fuel Cell Technologies [4]

There are also several challenges relative to fuel cell technology commercialization [5]. Cost and durability are the major barriers; however, several other hurdles exist depending upon which technology and application is employed. System size, air, and thermal and water management are all barriers to fuel cell technology commercialization.

A fuel processor converts fuel fed to the fuel cell into a usable form [6]. A processor may not be required when hydrogen is the feed gas; however, the hydrogen may need to be purified. If the system is powered by a hydrogen-rich, conventional fuel, such as methanol, gasoline, diesel, or gasified coal, a reformer is typically used to convert hydrocarbons into a gas mixture of hydrogen and carbon compounds called "reformate." In many cases, the reformate is then sent to another reactor to remove impurities to 
tolerable levels before it is sent to the fuel cell stack. This process prevents impurities in the gas from binding with the fuel cell catalysts. This binding process is also called "poisoning" because it reduces the efficiency and life expectancy of the fuel cell. It is important to note that when hydrogen is used as the fuel fed to the fuel cell, generally the hydrogen is produced by steam methane reforming of compressed natural gas. Further research efforts are ongoing to capture the carbon compounds produced during this process.

Some fuel cells, such as molten carbonate and solid oxide fuel cells, operate at temperatures high enough that the fuel can be reformed in the fuel cell itself. This is called internal reforming. Fuel cells that use internal reforming still need traps to remove impurities from the unreformed fuel before it reaches the fuel cell.

Both internal and external reforming release carbon dioxide, but less than the amount emitted by internal-combustion engines, such as those used in gasoline-powered vehicles.

In addition to the technologies discussed above, there are other types of fuel cells available, but not commonly used. Figure 5 shows a comparison of fuel cell technologies.

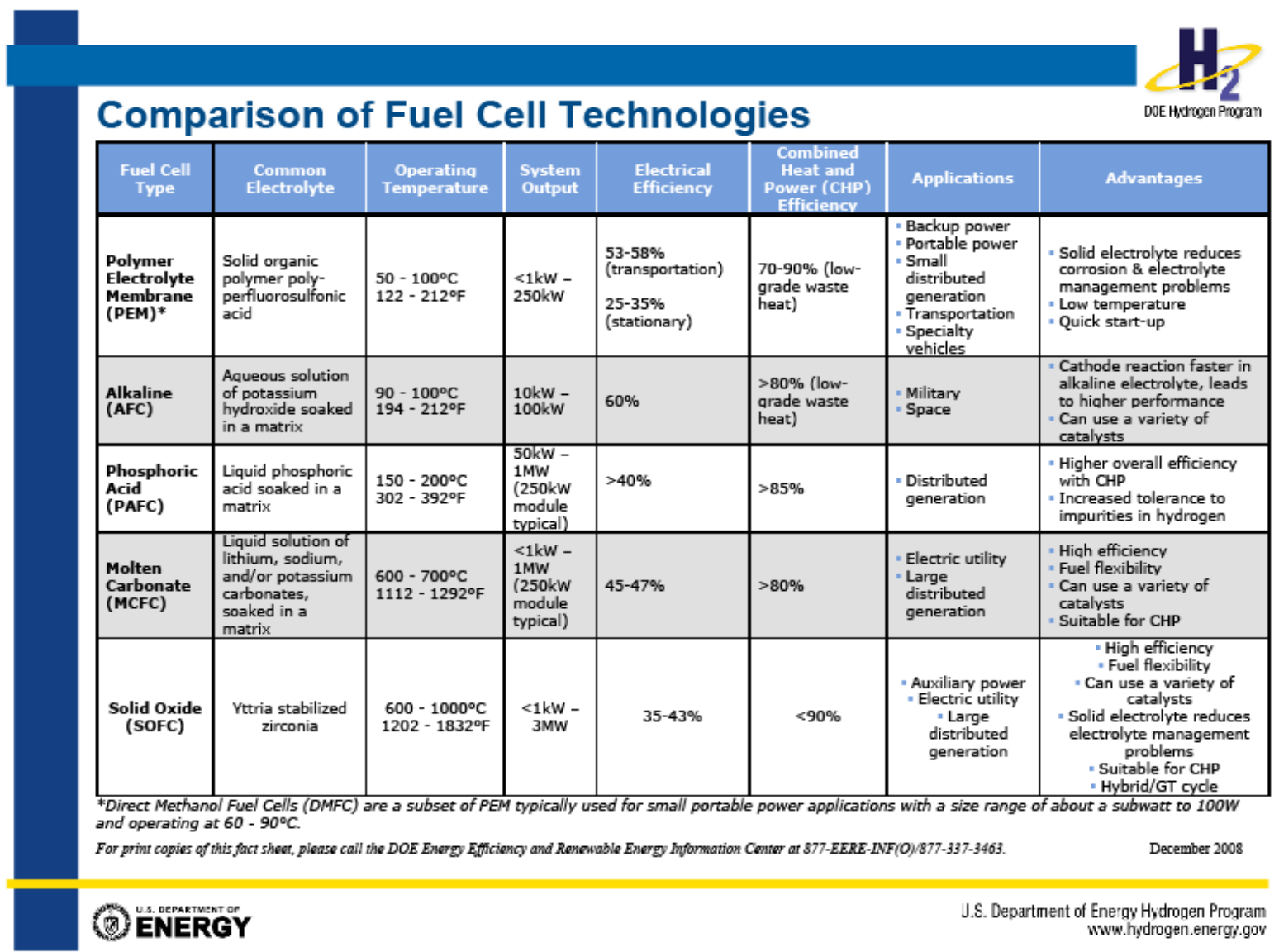

Figure 5: Comparison of Fuel Cell Technologies [7] 


\section{Codes and Standards Structure}

Table 3, below, contains citations for codes and standards that are applicable to stationary fuel cell applications. The citation set is generally focused on hydrogen applications and are for a typical application; however, there may be variations in specific jurisdications.

Table 3: Code and Standard citations for Stationary Fuel Cell Applications

\section{Codes and Standards Citations for Stationary Fuel Cell Applications}

\section{Construction Approval}

NFPA 70, National Electric Code (National Fire Protection Association, 2008) Article 692

ANSI/CSA America FC 1-2004, Stationary Fuel Cell Power Systems (American National Standards Institute and Canadian Standards Association, 2004)

1.2 Power Systems Design

1.3 General Design Requirements

1.3.2 Protection from Environmental Conditions

1.3.3 Electrical Safety

1.3.5 Steam Backflow

1.3.6 FC System Purging

1.3.7 Safe Handling During Moving

1.3.8 Shock and Vibration Protection

1.3.9 Requirements for Not-Listed Equipment

1.3.11 Temperature Limits

1.4 Materials

1.5 General Construction and Assembly

1.6 Enclosures and Associated Construction

1.8.1 Metallic Piping

1.9 Drain, Venting and Ventilation Exhaust Systems

1.12.1 Manual Valves

1.12.2 Automatic Valves

1.12.3 Pressure Regulators

1.15 Electrical Equipment and Wiring

1.19.1 Materials for Markings

1.19.2 FC Labeling Requirements

1.19.4 - 1.19.7 Electrical Diagrams

International Building Code (International Code Council, 2009)

307.1.1 Maximum Allowable Quantities

414.1 General

414.2 Control Areas

414.4 Hazardous Materials Systems

414.6 Outdoor Storage, Dispensing, and Use

907 Fire Alarms and Detection Systems

1609 Wind Loads

1612 Flood Loads

1805 Footings and Foundation 


\section{Codes and Standards Citations for Stationary Fuel Cell Applications}

International Fire Code (International Code Council, 2009)

401 General Emergency Planning and Preparedness

406 Employee Training and Response Procedures

2703.1 Hazardous Materials

2703.1.1 Maximum Allowable Quantities per Control Area

2703.1.3 Quantities Not Exceeding the Maximum Allowable Quantity per Control Area

2703.1.4 Quantities Exceeding the Maximum Allowable Quantity per Control Area

2703.2 Systems, Equipment, and Processes

2703.2.1 Design and Construction of Containers, Cylinders, and Tanks

2703.2.2 Piping, Tubing, Valves, and Fittings

2703.2.3 Equipment, Machinery, and Alarms

2703.2.4 Installation of Tanks

2703.2.5 Empty Containers and Tanks

2703.2.8 Seismic Protection

2703.2.9 Testing

2703.3 Release of Hazardous Materials

2703.4 Material Safety Data Sheets

2703.8 Construction Requirements

2703.8.1 Buildings

2703.8.2 Required Detached Buildings

2703.8.3 Control Areas

2703.8.4 Gas Rooms

2703.8.5 Exhausted Enclosures

2703.8.6 Gas Cabinets

2703.8.7 Hazardous Materials Storage Cabinets

2703.9 General Safety Precautions

2703.9.1 Personnel Training and Written Procedures

2703.9.1.1 Fire Department Liaison

2703.9.2 Security

2703.9.3 Protection from Stationary fuel cell applications

2703.9.4 Electrical Wiring and Equipment

2703.9.5 Static Accumulation

2703.9.6 Protection from Light

2703.9.7 Shock Padding

2703.9.8 Separations of Incompatible Materials

2703.9.9 Shelf Storage

2703.12 Outdoor Control Areas

2704 Storage

2705 Use, Dispensing, and Handling

3003.1 Containers, Cylinders, and Tanks

3003.2 Design and Construction

3003.3 Pressure Relief Devices

3003.4 Gas Marking

3003.4.1 Stationary Compressed Gas Containers, Cylinders, and Tanks 3003.4.2 Portable Containers, Cylinders, and Tanks 


\section{Codes and Standards Citations for Stationary Fuel Cell Applications}

3003.4.3 Piping Systems

3003.5 Security

3003.6 Valve Protection

3003.6.1 Compressed Gas Container, Cylinder, or Tank Protective Caps or

Collars

3003.7 Separations from Hazards

3003.8 Wiring and Equipment

3003.10 Unauthorized Use

3003.11 Exposure to Fire

3003.12 Leaks, Damage, or Corrosion

3003.13 Surface of Unprotected Storage or Use Areas

3003.14 Overhead Cover

3003.15 Lighting

3003.16.13 Accessway

3004 Storage of Compressed Gases

3005 Use and Handling of Compressed Gases

3005.1 Compressed Gas Systems

3005.2 Controls

3005.3 Piping Systems

3005.4 Valves

3005.5 Venting

3005.6 Upright Use

3005.7 Transfer

3005.9 Material-Specific Regulations

3005.10 Handling

3203.4 Liquid Marking

3503.1 Quantities Not Exceeding the Maximum Allowable Quantity per Control Area

3503.1.2 Storage Containers

3503.1.3 Emergency Shutoff

3503.1.4 Ignition Source Control

3503.1.5 Electrical

3503.2 Quantities Exceeding the Maximum Allowable Quantity per Control Area

3504.2 Outdoor Storage

3504.2.1 Distance Limitation to Exposures

3505 General Use

International Fuel Gas Code (International Code Council, 2009)

301 General

302 Structural Safety

303 Appliance Location

305 Installation

409 Shutoff Valves

633 Stationary Fuel Cell Power Systems

635 Gaseous Hydrogen Systems

703.2 Containers, Cylinders, and Tanks

703.3 Pressure Relief Devices

703.4 Venting 


\section{Codes and Standards Citations for Stationary Fuel Cell Applications}

703.5 Security

703.6 Electrical Wiring and Equipment

704 Piping, Use and Handling

705 Testing of Hydrogen Piping Systems

706 Location of Gaseous Hydrogen Systems

International Mechanical Code (International Code Council, 2009)

301 General

302 Protection of Structure

303 Equipment \& Appliance Location

304 Installation

305 Piping Support

401 General

501 Exhaust Systems

502 Required Systems

510 Hazardous Exhaust Systems

924 Stationary Fuel Cell Power Systems

926 Gaseous Hydrogen Systems

NFPA 55, Compressed Gases and Cryogenic Fluids Code (National Fire

Protection Association, 2010)

7.1.1 Listed and Approved Hydrogen Equipment

7.1.2 Containers, Cylinders and Tanks

7.1.3 Listed and Approved Hydrogen Equipment

7.1.4.3 Physical Protection

7.1.6 Separation from Hazardous Conditions

7.3.1.4 Valves

7.6 Flammable Gases

10.2 Design of Gaseous Hydrogen Systems

10.2.1 Pressure Relief Devices

10.2.1.1 Venting Requirements

10.2.5 Marking

10.3 Location of Gaseous Hydrogen Systems

10.3.2 Specific Requirements

10.4.1.2 Electrical Equipment Location

10.6 Fire Protection

NFPA 853, Standard for the Installation of Stationary Fuel Cell Power

Systems (National Fire Protection Association, 2007)

4.2 Prepackaged, Self-Contained Fuel Cell Power Systems

4.3 Pre-Engineered Fuel Cell Power Systems

4.4 Engineered and Field-Constructed Fuel Cell Power Systems

5.1.1 General Siting

5.1 .1 (2) General Siting

5.1.2 General Siting

5.1.3 General Siting

5.2 Outdoor Installations

6.1.2 General

6.4.1 Gaseous Hydrogen Storage

6.4.1 Ventilation Air 


\section{Codes and Standards Citations for Stationary Fuel Cell Applications}

6.4.3 Hydrogen Piping

6.4.3.2 Hydrogen Piping

6.4.3.5 Hydrogen Piping

6.4.3.7 Hydrogen Piping

6.4.3.1 Hydrogen Piping

7.1.1 General

7.2.2 When Natural ventilation Permitted

7.3 Exhaust Systems

8.1.2 Fuel Cell Fire Protection and Detection

8.1.3 Electrical Equipment and Components

9.2 Outdoor Installations

9.5 Fire Protection

\section{Operation Approval}

ANSI/CSA America FC 1-2004, Stationary Fuel Cell Power Systems (American National Standards Institute and Canadian Standards Association, 2004)

1.18.2 Maintenance Manual

1.19.1 Materials for Markings

1.19.2 FC Labeling Requirements

1.19.4 - 1.19.7 Electrical Diagrams

CGA P-1, Safe Handling of Compressed Gases in Containers (Compressed

Gas Association, 2006)

4.1 Transportation Regulating Authorities

4.2 Container Regulations

4.3 Container Filling Regulations

4.4 Regulating Authorities of Employee Safety and Health

6.2 Flammable Gases

International Fire Code (International Code Council, 2009)

105.6.8 Compressed Gases

404.3.2 Fire Safety Plans

406 Employee Training and Response Procedures

2703.2.6 Maintenance

2703.5 Hazard Identification Signs

2703.6 Signs

2705 Use, Dispensing, and Handling

3003.4 Gas Marking

3003.9 Service and Repair

3003.16.13 Accessway

3005.7 Transfer

3203.4 Liquid Marking

3505 General Use

International Fuel Gas Code (International Code Council, 2009)

707 Operation and Maintenance of Gaseous Hydrogen Systems 


\section{Codes and Standards Citations for Stationary Fuel Cell Applications}

NFPA 55, Compressed Gases and Cryogenic Fluids Code (National Fire Protection Association, 2010)

4.6 Personnel Training

4.7 Fire Department Liaison

7.1.3 Listed and Approved Hydrogen Equipment

7.3.1.10 Use and Handling

8.3.5 Overfilling

10.2.5 Marking

10.3 Location of Gaseous Hydrogen Systems

10.6 Fire Protection

NFPA 853, Standard for the Installation of Stationary Fuel Cell Power

Systems (National Fire Protection Association, 2007)

6.1.2 General

6.4.1 Gaseous Hydrogen Storage

6.4.3 Hydrogen Piping

8.2 Fire Prevention and Emergency Planning 


\section{Gaps in Codes and Standards}

\section{Model and Design Codes}

Model codes and standards exist for the installation of stationary fuel cell applications. In general, the codes and standards are complete with no large gaps. However, in some cases, there is some confusion that exists at the installer and inspector level, generally regarding the storage of alternative fuels. For example, an instance was cited where neither party could determine which separation distances apply according to NFPA 55, 10.3.2.2.2.

\section{Appliances and Generators}

There are currently no listings that apply to hydrogen generators that are not a part of the fuel cell system. The Underwriters Laboratory (UL) listing for generators is currently held up because the Compressed Gas Association (CGA) has not granted rights to ISO for referencing CGA standards. Until this gap is filled, FC-1 and NFPA 853 could be used.

\section{Component Standards}

Currently, there are no component standards for hydrogen use in low- and high-pressure systems, including valves, regulators, fittings, flexible connectors, etc.

\section{Qualification Testing}

Qualification testing standards for plastic and composite components need to be developed.

\section{Hazardous Waste}

Some fuel cell systems with internal reformers contain materials that are considered hazardous waste when removed from the system for replacement. This waste disposal issue may add to the system cost and could be potentially addressed through using less hazardous materials.

\section{Fuel Quality}

There is currently no fuel quality specification standard for stationary fuel cell applications that utilize hydrogen as a fuel. ISO TC197 Working Group 14 has been formed for the purpose of drafting a fuel specification standard. Domestically, industry focus is to utilize SAE J2719 specification as a reference in CGA 5.5.

\section{Product Standard Including “Bumping” Refills of Stationary Storage}

There is no domestic product standard for the dispensing of hydrogen for stationary fuel cell applications. Furthermore, there is no process for refilling stationary storage systems for stationary fuel cell applications (bumping). The fuel cells used for backup power typically do not require frequent filling or cylinder replacement so this has not been an issue that has impeded operating fuel cells.

\section{Coordination of International and Domestic Fuel Cell Standards}

Most fuel cell manufacturers sell their products in more than one country. Selling in multiple country markets can create the need for coordination between U.S. and international fuel cell standards. This coordination has been, for the most part, addressed through industry representation on domestic and international standards development committees. 


\section{Summary}

Table 4 presents a summary of the identified Codes and Standards Gaps for alternative fuels used with stationary fuel cell systems. Also included in the table is the impacted document and proposed means to address the gap.

Table 4: Codes and Standards Gaps for Stationary Fuel Cell Applications

\section{Codes and Standards Gap \\ Documents Impacted \\ Gap Resolution}

\begin{tabular}{|c|c|c|}
\hline $\begin{array}{l}\text { Model and Design Codes - } \\
\text { Coordination Issues }\end{array}$ & $\begin{array}{l}\text { NFPA 55, NFPA 853, } \\
\text { ASME B31.12, CGA } \\
\text { F/C } 1\end{array}$ & $\begin{array}{l}\text { Work with the SDOs and } \\
\text { assist as needed to ensure } \\
\text { the required cross } \\
\text { references are placed in } \\
\text { the installation and storage } \\
\text { documents. }\end{array}$ \\
\hline $\begin{array}{l}\text { Appliances/Generators - UL listing } \\
\text { is held up at CGA by not granting } \\
\text { rights in ISO documents ( } 22374) \text { for } \\
\text { reference }\end{array}$ & $\begin{array}{l}\text { UL } 2264 \text { A,B, and C, } \\
\text { CGA documents, ISO } \\
22374\end{array}$ & $\begin{array}{l}\text { Work with SDOs to develop } \\
\text { a path for referencing CGA } \\
\text { documents. }\end{array}$ \\
\hline $\begin{array}{l}\text { Component Standards for hydrogen } \\
\text { use in low- and high-pressure } \\
\text { systems (valves, regulators, fittings, } \\
\text { flexible connectors, etc.) need more } \\
\text { detailed requirements, such as } \\
\text { those found in NFPA } 54 \text { for natural } \\
\text { gas applications }\end{array}$ & NFPA 853 and FC-1 & $\begin{array}{l}\text { Review existing documents } \\
\text { for natural gas, specifically } \\
\text { NFPA 54, and consider } \\
\text { writing parallel } \\
\text { requirements in NFPA } 853 \\
\text { and FC-1. }\end{array}$ \\
\hline $\begin{array}{l}\text { Qualification Testing Standards for } \\
\text { plastic and composite components }\end{array}$ & UL, CGA, CSA, ASTM & $\begin{array}{l}\text { Develop testing standards } \\
\text { for system components as } \\
\text { needed - NFPA } 853 \text { and } \\
\text { FC-1. }\end{array}$ \\
\hline $\begin{array}{l}\text { Coordination of International and } \\
\text { Domestic Fuel Cell Standards }\end{array}$ & $\begin{array}{l}\text { Multiple SDOs and } \\
\text { documents }\end{array}$ & $\begin{array}{l}\text { Track domestic and } \\
\text { international fuel cell } \\
\text { standards to ensure no } \\
\text { major conflicts impede the } \\
\text { applications of fuel cell } \\
\text { technologies. }\end{array}$ \\
\hline
\end{tabular}




\begin{tabular}{|c|c|c|}
\hline $\begin{array}{l}\text { There is currently no hydrogen Fuel } \\
\text { Quality Standard written specifically } \\
\text { for fuel cells }\end{array}$ & CGA, ISO & $\begin{array}{l}\text { There is a CGA commodity } \\
\text { standard for hydrogen that } \\
\text { is currently being used for } \\
\text { fuel cells. On the } \\
\text { International level ISO } \\
\text { T/C197 Hydrogen } \\
\text { technologies Working } \\
\text { Group } 14 \text { is developing a } \\
\text { fuel quality standard for } \\
\text { hydrogen for stationary fuel } \\
\text { cells. Domestically, } \\
\text { industry focus is to utilize } \\
\text { SAE J2719 specification as } \\
\text { a reference in CGA } 5.5 \text {. }\end{array}$ \\
\hline $\begin{array}{l}\text { Lack of understanding of fuel cell } \\
\text { technology, specifically the storage } \\
\text { of alternative fuels, on the part of } \\
\text { enforcing authorities }\end{array}$ & Multiple documents & $\begin{array}{l}\text { Continue outreach to code } \\
\text { officials in the form of web } \\
\text { materials, online training, } \\
\text { and codes and standards } \\
\text { workshops. }\end{array}$ \\
\hline
\end{tabular}




\section{Conclusion}

The previous sections presented the status of the codes and standards for stationary fuel cell applications. The broad conclusion of this report is that, because of the development of several key documents, and Article 692 of the NEC, stationary conventionally fueled fuel cell systems can be installed and operated without significant codes and standards delays. There is an ongoing need to coordinate alternative fuel storage installation and component product safety standards, and domestic and international standards. The mechanisms to accomplish this coordination are to a large extent in place and functional. These mechanisms include industry participation on the various codes and standards technical committees responsible for these various aspects of fuel cells, and DOE monitoring and participation in the codes and standards development process.

The stationary fuel cell technologies that currectly are being commercially applied are:

\section{PEM \\ 2.Phosphoric Acid \\ 3.Molten Carbonate \\ 4. Solid Oxide}

Although there are several fuels that are used to power stationary fuel cells, hydrogen, as it does with other applications, presents some of the greatest codes and standards challenges. These challenges include siting hydrogen storage systems, identifying materials and components compatible with hydrogen use, and educating code officials on how hydrogen is used in fuel cells. There were cases were hydrogen powered fuel cells were initially viewed as combustion devices (i.e. boilers) and combustion requirements were to be applied. 


\section{References}

1. U.S. Department of Energy, Hydrogen Program "Introduction to Hydrogen for Code Officials." http://www.hydrogen.energy.gov/code_official_training.html. Accessed August 2, 2010

2. U.S. Department of Energy, Hydrogen Program "Permitting Hydrogen Facilities." Hydrogen Fueling Station Related Links http://www.hydrogen.energy.gov/permitting/stations_related.cfm. Accessed August 2, 2010

3. American National Standards Institute (ANSI), "Standards Activities Overview." Overview of the U.S. Standardization System http://www.ansi.org/standards_activities/overview/overview.aspx. Accessed August 2, 2010

4. California Stationary Fuel Cell Collaborative "Fuel Cell Technologies." http://www.casfcc.org/2/StationaryFuelCells/FuelCellTechnologies.aspx. Accessed August 2, 2010

5. Energy Efficiency \& Renewable Energy, Fuel Cells "Fuel Cell Technology Challenges." http://www1.eere.energy.gov/hydrogenandfuelcells/fuelcells/fc_challenges.html. Accessed August 2, 2010

6. Energy Efficiency \& Renewable Energy, Fuel Cells "Fuel Cell Systems." http://www1.eere.energy.gov/hydrogenandfuelcells/fuelcells/fc_systems.html. Accessed August 2, 2010

7. Energy Efficiency \& Renewable Energy, Fuel Cells "Types of Fuel Cells." http://www1.eere.energy.gov/hydrogenandfuelcells/fuelcells/fc_types.html. Accessed August 2, 2010 


\section{APPENDIX I:}

\section{Biographies (in alphabetical order):}

\section{Connie Bielawski, MBA}

Project Manager

Ms. Bielawski is a Project Manager in the Alternative Energy Program at CSA. Ms. Bielawski is responsible for managing and providing support to Technical and Advisory Committees for Natural Gas and Hydrogen Vehicle related Standards Development projects. Ms. Bielawski is the secretariat for TC 105 Working Groups 1, 3, and 8. Ms. Bielawski holds a Bachelor's Degree in Biology and a Master of Business Administration from Cleveland State University.

\section{Chad Blake}

Senior Project Leader, NREL

Chad Blake is a Senior Project Leader in the Codes and Standards Group of the Hydrogen Technologies and Systems Center at NREL in Golden, Colorado. He has worked at several DOE laboratories for 15 years in nuclear, energy, government, operations, and research environments. He joined NREL in 2007 and currently leads codes and standards hydrogen fuel quality efforts as well as R\&D on other renewable transportation fuels. He is a member of the International Energy Agency's Task 19, the DOE Hydrogen Safety Panel, and several codes and standards related committees.

\section{William P. Collins}

\section{UTC Power}

William Collins holds a Bachelor of Science in mechanical engineering from the University of Connecticut and a Master of Science in management from Rensselaer Polytechnic Institute. Mr. Collins has more than 30 years experience in the fields of power generation, fuel cells, and hydrogen. He is a member of the SAE Fuel Cell Vehicles Standards Committee, the CSA America Fuel Cell Tag, the NFPA Electrical Generating Committee, the ASME B31 Section 12 book committee, and the US-TAG for ISO TC197. 
Biographies (in alphabetical order):

\section{Michael M. Penev}

Senior Analyst, NREL

Michael Penev provides techno-economic analysis for hydrogen infrastructure and fuel cell technology deployment scenarios and advises on fuel cell market transformation activities. Additionally, Michael represents NREL on DOE's Hydrogen Production Technology Team, which consults on hydrogen production pathways and reviews project progress.

Previous to joining NREL, Mr. Penev was employed for 7 years by Plug Power Inc in Latham, New York and 1 year in the Netherlands. In this position he worked as a systems engineer and specialized in fuel processor and fuel cell system design, as well as system integration. Mr. Penev has extensive experience with both PEM and PBI fuel cell systems.

Mr. Penev holds a master's degree in mechanical engineering from Union College in Schenectady, New York, and a bachelor's degree in chemical engineering from the University of Washington in Seattle, Washington.

\section{Chris Radley}

Altergy Systems

Mr. Radley leads Altergy's Product Line Management organization, which includes Field Services. Prior to this, he led Altergy's Product and Process Engineering department. During his tenure, his team developed and listed Altergy's Freedom Power System product line for stationary backup power applications. He has worked with more than 80 local U.S. jurisdictions to obtain building permits related to the installation of stationary fuel cell power systems and has trained more than 300 firefighters on fuel cell and hydrogen safety.

Mr. Radley earned his Master of Business Administration degree from the University of California-Davis, and his Master of Science degree in Mechanical Engineering from California State University-Sacramento. He attained a Bachelor of Science degree in Aeronautical Engineering from Rensselaer Polytechnic Institute in Troy, New York. Mr. Radley was also a volunteer firefighter for 10 years. 
Biographies (in alphabetical order):

Carl Rivkin, P.E.

Senior Project Leader II, NREL

Mr. Rivkin is the project leader for the Codes and Standards Project team at NREL in Golden, Colorado. The Codes and Standards Group at NREL has responsibility for implementing the U.S. National Template of Codes and Standards for alternative fuels for stationary fuel cell applications. This implementation effort runs the gamut from running a sensor test laboratory to evaluating the performance of chemical sensors to conducting codes and standards seminars to assisting code officials in permitting facilities.

Mr. Rivkin has more than 25 years of experience in safety and environmental engineering, including work at a regulatory agency. Prior to joining NREL, Mr. Rivkin worked for the NFPA on alternative energy code projects. He was also the editor of "The NFPA Guide to Gas Safety," published in 2005, which has several chapters devoted to hydrogen and flammable gas safety.

Mr. Rivkin has a bachelor's degree in chemical engineering from the University of Michigan and an MBA from the University of Baltimore. He is a licensed Professional Engineer and Certified Safety Professional.

\section{Douglas Wheeler}

DJW Technology

Douglas Wheeler is the owner of DJW TECHNOLOGY. Mr. Wheeler received his Master of Science from Case Western Reserve University and has more than 40 years of experience in research, development, demonstration, and commercialization of energy technologies. Mr. Wheeler managed UTC Fuel Cells Advanced Technology Group and guided UTC Fuel Cells' PEM technology team during the transition from Phosphoric Acid fuel cells to PEM fuel cells. He has participated in the commercialization of fuel cell systems and the development of hydrogen production technology. He was invited by DOE to review the status of fuel cell technology in Finland and worked with Sandia National Laboratory assessing Russian fuel cell technology for DOE. A cooperative research and development program was established with Russia and Sandia National Laboratory to develop fuel cell bipolar plates. Mr. Wheeler has conducted technical, manufacturing, and economic assessments of fuel cells and hydrogen technology. Mr. Wheeler has 18 U.S. Patents. 
Biographies (in alphabetical order):

Joseph Zerbo

Power Generation Consultant - Salt River Project, Phoenix Valley, Arizona

Mr. Zerbo provides engineering assistance and training support to all generation facilities at the Salt River Project (SRP). He is responsible for the operations and maintenance of SRP's renewable energy assets after their commissioning. Mr. Zerbo has 35 years of power generations operational experience and holds a Bachelor of Science degree from the State University of New York. 


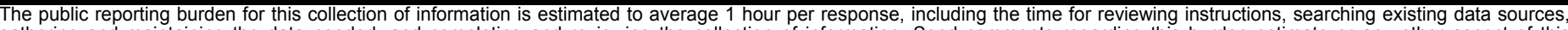

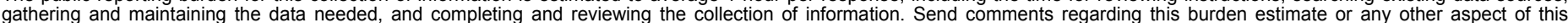

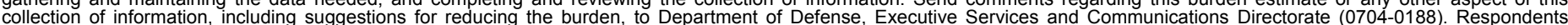

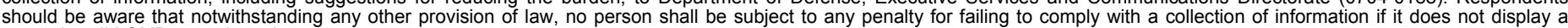

should be aware that notwithstand

PLEASE DO NOT RETURN YOUR FORM TO THE ABOVE ORGANIZATION.

\begin{tabular}{l|l|l|l} 
1. REPORT DATE $(D D-M M-Y Y Y Y)$ & 2. REPORT TYPE & 3. DATES COVERED (FrOm - TO)
\end{tabular}

September 2010

4. TITLE AND SUBTITLE

Stationary Fuel Cell Application Codes and Standards: Overview and Gap Analysis 5a. CONTRACT NUMBER

DE-AC36-08-GO28308

5b. GRANT NUMBER

5c. PROGRAM ELEMENT NUMBER

5d. PROJECT NUMBER

NREL/TP-560-49165

5e. TASK NUMBER

$\mathrm{H} 274.7170$

5f. WORK UNIT NUMBER
7. PERFORMING ORGANIZATION NAME(S) AND ADDRESS(ES)

National Renewable Energy Laboratory

1617 Cole Blvd.

Golden, CO 80401-3393
8. PERFORMING ORGANIZATION REPORT NUMBER

NREL/TP-560-49165

9. SPONSORING/MONITORING AGENCY NAME(S) AND ADDRESS(ES)

10. SPONSOR/MONITOR'S ACRONYM(S) NREL

11. SPONSORING/MONITORING AGENCY REPORT NUMBER

12. DISTRIBUTION AVAILABILITY STATEMENT

National Technical Information Service

U.S. Department of Commerce

5285 Port Royal Road

Springfield, VA 22161

13. SUPPLEMENTARY NOTES

14. ABSTRACT (Maximum 200 Words)

This report provides an overview of codes and standards related to stationary fuel cell applications and identifies gaps and resolutions associated with relative codes and standards. The Codes and Standards Group at the National Renewable Energy Laboratory (NREL) conducted an analysis of the full range of codes and standards that apply to stationary fuel cell applications to determine where the gaps are located in the codes and standards and what work must be performed to fill these gaps. The major codes and standards are in place to allow for the implementation of stationary fuel cells.

15. SUBJECT TERMS

stationary fuel cells; codes and standards; gap analysis; fuel cell

\begin{tabular}{|c|c|c|}
\hline $\begin{array}{l}\text { a. REPORT } \\
\text { Unclassified }\end{array}$ & $\begin{array}{l}\text { b. ABSTRACT } \\
\text { Unclassified }\end{array}$ & $\begin{array}{l}\text { c. THIS PAGE } \\
\text { Unclassified }\end{array}$ \\
\hline
\end{tabular}

\begin{tabular}{|c|c|}
\hline $\begin{array}{l}\text { 17. LIMITATION } \\
\text { OF ABSTRACT }\end{array}$ & $\begin{array}{l}\text { 18. NUMBER } \\
\text { OF PAGES }\end{array}$ \\
\hline UL & \\
\hline
\end{tabular}

19a. NAME OF RESPONSIBLE PERSON

19b. TELEPHONE NUMBER (Include area code) 